\title{
HUBUNGAN PENGELUARAN ROKOK RUMAH TANGGA DENGAN STATUS GIZI BALITA DI INDONESIA (ANALISIS DATA RISKESDAS 2010)
}

\author{
Sudikno'; Bona Simanungkalit2; Yekti Widodo' dan Sandjaja² \\ 'Pusat Teknologi Intervensi Kesehatan Masyarakat \\ ${ }^{2}$ Pusat Teknologi Terapan Kesehatan dan Epidemiologi Klinik
}

\section{ABSTRAK}

Tingkat pendapatan masyarakat diperberat oleh pengeluaran rokok rumah tangga yang secara tidak langsung akan mempengaruhi status gizi balita. Penelitian ini bertujuan mengetahui hubungan pengeluaran rokok rumah tangga dengan status gizi balita. Penelitian menggunakan data Riskesdas 2010. Populasi penelitian meliputi semua rumah tangga Riskesdas 2010. Sedangkan sampel adalah semua rumah tangga Riskesdas 2010 yang memiliki balita ( $0-59$ bulan) dengan kriteria inklusi balita ( $0-59$ bulan) termuda di rumah tangga. Variabel penelitian meliputi: status gizi balita, pengeluaran rokok rumah tangga, pendidikan KK, pekerjaan KK, tinggi badan ibu, pendidikan ibu, pekerjaan ibu, dan status sosial ekonomi. Hasil penelitian menunjukkan rumah tangga dengan pengeluaran rokok pada kuintil 4 dan 5 memiliki odds rasio 1,21 kali untuk memiliki balita dengan status gizi (BB/TB) kurus dan sangat kurus dibandingkan rumah tangga dengan pengeluaran rokok pada kuintil 1, 2, dan 3 setelah dikontrol oleh variabel pendidikan ibu, pendidikan KK, dan pekerjaan KK.

Kata kunci: pengeluaran rokok, rumah tangga, status gizi balita

\section{ABSTRACT}

\section{THE RELATIONSHIP BETWEEN CIGARETTE SPENDING AND INFANT NUTRITION STATUS IN INDONESIA (DATA ANALYSIS OF BASIC HEALTH RESEARCH 2010)}

Level of community income was burdened by spending on cigarette that indirectly effected infant nutrition status. The objective of this study is to know the relationship of cigarette spending and infant nutrition status. The study used Basic Health Research data 2010. The population were all household in that research and the samples were all households that had infants (0-59 months) with the youngest infants as the inclusion criteria. The variables collected were infant nutrition status, cigarette spending, family head's education, family head's occupation, mother's height, mother's education, and social economic status. The result showed that household with cigarette spending in quintil 4 and 5 had odds ratio 1.21 times higher to have infants with wasted (weight/height) and severe wasted compared to those with cigarette spending in quintil 1, 2, and 3 after controlled by variables namely; mother's education, family head's education, and family head's occupation.

Keywords: cigarette spending, house hold, infant nutrition status

\section{PENDAHULUAN}

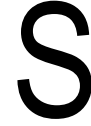
alah satu tujuan yang ditargetkan dalam Millenium Development Goals (MDGs) adalah menurunkan prevalensi underweight. Komponen indikator status gizi (underweight) merupakan salah satu penilaian dalam menghitung Human Development Index (HDI) dimana Indonesia masih berada pada posisi 112 dari 175 negara dan pada tahun 2005 sedikit berubah pada peringkat 108 dari 177 negara lebih rendah dari Singapura, Malaysia, Brunai, dan Thailand.1,2 Selain dari sektor kesehatan tersebut, HDI juga ditentukan dari sektor pendidikan dan ekonomi. ${ }^{2}$

Status gizi anak merupakan indikator yang penting yang dipengaruhi oleh tiga determinan, yaitu: determinan langsung, determinan tidak langsung, dan determinan dasar. ${ }^{3}$ Determinan langsung merupakan faktor yang terdapat pada tingkat individu, seperti status kesehatan dan infeksi. Determinan tidak langsung merupakan determinan yang terdapat pada tingkat rumah tangga, misalnya: ketersediaan pangan di tingkat rumah tangga, perawatan anak, dan pelayanan kesehatan, termasuk kesehatan lingkungan. Lingkungan, baik secara fisik 
maupun biologis, sangat berperan dalam proses terjadinya gangguan kesehatan masyarakat, termasuk gangguan kesehatan berupa penyakit pada anak balita. Sedangkan determinan dasar adalah potensi sumber daya yang ada di suatu negara, termasuk kondisi sosial ekonomi dan politik. $^{4}$

Beberapa studi menunjukkan bahwa keadaan sosial ekonomi rumah tangga menentukan status gizi anak balita, di samping faktor lainnya, seperti: jumlah anggota rumah tangga, pelayanan kesehatan, penyakit infeksi, dan kondisi kesehatan lingkungan rumah tangga. Kemiskinan merupakan penyebab kurang gizi yang paling sering dijumpai di berbagai negara. Masyarakat miskin di negara berkembang menggunakan sebagian besar pendapatannya untuk memenuhi kebutuhan pangan. Dengan terbatasnya pendapatan, ketersediaan pangan di tingkat rumah tangga juga berkurang, baik jumlah maupun mutunya, sehingga konsumsi makanan juga mengalami penurunan dan selanjutnya status gizinya relatif rendah.

Studi Riyadi H., dkk. di daerah Bogor dan Indramayu pada tahun 2005 menunjukkan bahwa masalah gizi pada anak balita prevalensinya lebih besar pada anak balita dari rumah tangga miskin dibandingkan anak balita pada rumah tangga tidak miskin. ${ }^{5}$ Kecukupan protein pada keluarga miskin lebih rendah dibandingkan rumah tangga tidak miskin. ${ }^{6}$ Selanjutnya data SUSENAS menunjukkan bahwa semakin tinggi tingkat pendapatan maka semakin tinggi tingkat konsumsi energi dan protein, selain itu mutu makanannya juga semakin baik. ${ }^{7}$

Menurut Moeloek (2010) bahwa rendahnya tingkat pendapatan masyarakat diperberat dengan biaya langsung untuk membeli rokok pada tingkat rumah tangga atau individu (http:/community.um.ac.id). Selanjutnya Damayanti menambahkan bahwa anggota keluarga yang merokok dapat mempengaruhi status gizi balita yang tinggal serumah, konsumsi energi balita yang rumah tangganya ada yang merokok lebih rendah daripada yang rumah tangganya tidak ada yang merokok. ${ }^{8}$

Dari data Bappenas diketahui bahwa kebiasaan merokok di Indonesia bagi laki-laki sebesar 45,8 persen dan 3 persen pada perempuan, dan menurut kelompok umur sebesar 34,3 persen pada penduduk berusia 25 tahun ke atas dan 29,2 persen pada penduduk di atas 10 tahun. ${ }^{9}$ Selanjutnya diketahui pula bahwa pengeluaran untuk tembakau dan sirih menyumbang sebesar 4,97 persen pada tahun 2007 dan 5,08 persen pada tahun 2008 dari total pengeluaran rata-rata per kapita. ${ }^{10}$

Sedangkan data Riskesdas 2007 menunjukkan bahwa persentase penduduk umur 10 tahun ke atas yang merokok tiap hari sebesar 24 persen, persentase tertinggi terdapat pada kelompok umur produktif (25-64 tahun) dengan rerata 29 persen sampai dengan 32 persen. Sedangkan menurut jenis kelamin diketahui bahwa hampir separuh (45,8\%) penduduk laki-laki merupakan perokok tiap hari. Selanjutnya persentase perokok berdasarkan tingkat sosial ekonomi hampir tidak menunjukkan adanya perbedaan, persentase perokok kelompok sosial ekonomi rendah 35,8 persen sedangkan pada kelompok sosial ekonomi tinggi 31,5 persen. Dilihat dari persentase rumah tangga yang memiliki perokok, yaitu sebesar 69 persen. Hal ini berarti minimal terdapat satu orang anggota rumah tangga yang mengonsumsi rokok. ${ }^{2}$

Menurut kajian Ikatan Ahli Kesehatan Masyarakat Indonesia (IAKMI) (2010) secara nominal pengeluaran rumah tangga untuk membeli rokok meningkat dari Rp. 103.356 pada tahun 2003 menjadi Rp. 117.624 per bulan pada tahun 2006. ${ }^{11}$ Studi Kosen, dkk. (2009) menunjukkan bahwa kerugian ekonomi total penduduk Indonesia dalam setahun akibat konsumsi produk tembakau mencapai Rp. 338, 75 triliun, atau lebih dari enam kali pendapatan cukai rokok pemerintah Indonesia yang hanya Rp. 53,9 triliun. $^{12}$

Dengan melihat kondisi tersebut di atas, maka akan dilakukan analisis lanjut untuk mengetahui hubungan pengeluaran rokok rumah tangga dengan status gizi balita dengan menggunakan data Riskesdas 2010.

\section{METODE PENELITIAN}

Jenis penelitian ini adalah deskriptif dengan desain potong lintang (cross-secsional). Populasi adalah semua rumah tangga Riskesdas 2010. Sedangkan sampel adalah semua rumah tangga Riskesdas 2010 yang mempunyai balita (0-59 bulan). Kriteria inklusi pada penelitian ini adalah rumah tangga 
Riskesdas 2010 dengan balita (0-59 bulan) termuda.

Data yang digunakan untuk penelitian ini adalah Riskesdas 2010 dengan rincian kuesioner RKD10.RT dan RKD10.IND.

\section{Instrumen dan cara pengumpulan data}

Data pada analisis lanjut ini menggunakan data sekunder Riskesdas 2010. Variabel penelitian meliputi: i) variabel terikat, yaitu: status gizi balita (BB/TB, TB/U, BB/U); ii) variabel bebas utama: pengeluaran rokok rumah tangga; iii) variabel pengganggu, yang terdiri dari: pendidikan kepala keluarga, pekerjaaan kepala keluarga, tinggi badan ibu, pendidikan ibu, pekerjaan ibu, status ekonomi. Cara pengumpulan data adalah dengan wawancara dan pengukuran antropometri.

\section{Manajemen data}

Tahapan dalam manajemen data meliputi: analisis univariat, analisis bivariat, dan analisis multivariat. Analisis univariat untuk melihat distribusi masing-masing variabel, sedangkan analisis bivariat untuk mengetahui distribusi status gizi balita (BB/TB, TB/U, BB/U) menurut variabel bebas utama (pengeluaran rokok rumah tangga) dan variabel pengganggu (pendidikan KK, pekerjaan KK, TB ibu, pendidikan ibu, pekerjaan ibu, dan status ekonomi). Analisis regresi logistik digunakan untuk mengetahui hubungan pengeluaran rokok rumah tangga dengan status gizi balita (BB/TB, $T B / U, B B / U$ ) dikontrol variabel pengganggu (pendidikan KK, pekerjaan KK, TB ibu, pendidikan ibu, pekerjaan ibu, dan status ekonomi).

\section{HASIL}

\section{Karakteristik Balita}

Dari Tabel 1 diketahui bahwa jumlah responden yang dianalisis sebanyak 11500 balita, yang terdiri dari laki-laki $(50,50 \%)$ dan perempuan sebesar 49,50 persen.

Tabel 1

Karakteristik Balita, Riskesdas 2010

\begin{tabular}{llrr}
\hline & Variabel & $\mathrm{n}=11500$ & $\%$ \\
\hline Jenis kelamin & Laki-laki & 5687 & 49,50 \\
& Perempuan & 5813 & 50,50 \\
\hline Kelompok umur & 0-11 bulan & 1534 & 13,34 \\
& 12-23 bulan & 2580 & 22,43 \\
& 24-35 bulan & 2578 & 22,42 \\
& 36-47 bulan & 2556 & 22,23 \\
& 48-59 bulan & 2252 & 19,58 \\
\hline Status gizi (BB/TB) & Sangat kurus & 635 & 5,52 \\
& Kurus & 827 & 7,19 \\
& Normal & 8716 & 75,79 \\
& Gemuk & 1322 & 11,50 \\
\hline Status gizi (TB/U) & Sangat pendek & 2494 & 21,69 \\
& Pendek & 2473 & 21,50 \\
& Normal & 6533 & 56,81 \\
\hline Status gizi (BB/U) & Buruk & 561 & 4,88 \\
& Kurang & 1902 & 16,54 \\
& Baik & 8752 & 76,10 \\
& Lebih & 285 & 2,48 \\
\hline
\end{tabular}


Menurut kelompok umur balita, jumlah balita pada kelompok umur 0-11 bulan paling sedikit yaitu 13,34 persen dibandingkan dengan kelompok umur lainnya. Dari status gizi balita (BB/TB) diketahui bahwa persentase balita sangat kurus dan balita kurus masing-masing adalah 5,52 persen dan 7,19 persen. Kemudian dari status gizi balita (TB/U) didapatkan balita sangat pendek sebesar 21,69 persen dan balita pendek sebesar 21,50 persen. Selanjutnya dari status gizi balita $(\mathrm{BB} / \mathrm{U})$ diketahui bahwa balita dengan gizi buruk sebesar 4,88 persen dan balita dengan gizi kurang sebesar 16,54 persen, sedangkan balita dengan status gizi lebih sebesar 2,48 persen (Tabel 1).

Menurut karakteristik keluarga diketahui bahwa umur kepala keluarga (KK) maupun ibu balita sebagian besar berada pada kelompok umur 20-40 tahun yaitu masing-masing sebesar 67,65 persen dan 90,86 persen, pendidikan kepala keluarga dan ibu balita sebagian besar adalah SD ke bawah, yaitu masing-masing sebesar 45,55 persen dan 42,78 persen (Tabel 2).

Tabel 2

Karakteristik Keluarga, Riskesdas 2010

\begin{tabular}{|c|c|c|c|}
\hline \multicolumn{2}{|c|}{ Variabel } & $n=11500$ & $\%$ \\
\hline \multirow[t]{3}{*}{ Umur KK } & $<20$ tahun & 7 & 0,06 \\
\hline & 20-40 tahun & 7780 & 67,65 \\
\hline & $>40$ tahun & 3713 & 32,29 \\
\hline \multirow[t]{4}{*}{ Pendidikan KK } & $<=\mathrm{SD}$ & 5238 & 45,55 \\
\hline & SMP & 2207 & 19,19 \\
\hline & SMA & 3132 & 27,23 \\
\hline & PT & 923 & 8,03 \\
\hline \multirow[t]{4}{*}{ Pekerjaan KK } & TNI/PNS/Sekolah & 1290 & 11,22 \\
\hline & Wiraswasta/pedagang & 3977 & 34,58 \\
\hline & Tidak kerja/lainnya & 639 & 5,56 \\
\hline & Petani/nelayan/buruh & 5594 & 48,64 \\
\hline \multirow[t]{3}{*}{ Umur ibu } & $<20$ tahun & 238 & 2,07 \\
\hline & 20-40 tahun & 10449 & 90,86 \\
\hline & $>40$ tahun & 813 & 7,07 \\
\hline \multirow[t]{2}{*}{ Tinggi badan ibu } & $<150 \mathrm{~cm}$ & 4521 & 39,31 \\
\hline & $>=150 \mathrm{~cm}$ & 6979 & 60,69 \\
\hline \multirow[t]{4}{*}{ Pendidikan ibu } & $<=\mathrm{SD}$ & 4920 & 42,78 \\
\hline & SMP & 2633 & 22,90 \\
\hline & SMA & 3032 & 26,36 \\
\hline & PT & 915 & 7,96 \\
\hline \multirow[t]{3}{*}{ Pekerjaan ibu } & Tidak bekerja & 5989 & 52,08 \\
\hline & PNS/TNI/Wiraswasta & 2137 & 18,58 \\
\hline & Petani/buruh/nelayan & 3374 & 29,34 \\
\hline \multirow[t]{5}{*}{ Status ekonomi } & Kuintil 1 & 2770 & 24,08 \\
\hline & Kuintil 2 & 2656 & 23,10 \\
\hline & Kuintil 3 & 2451 & 21,31 \\
\hline & Kuintil 4 & 2150 & 18,70 \\
\hline & Kuintil 5 & 1473 & 12,81 \\
\hline \multirow[t]{5}{*}{ Pengeluaran rokok rumah tangga } & Kuintil 1 & 3194 & 27,77 \\
\hline & Kuintil 2 & 1406 & 12,23 \\
\hline & Kuintil 3 & 2300 & 20,00 \\
\hline & Kuintil 4 & 2300 & 20,00 \\
\hline & Kuintil 5 & 2300 & 20,00 \\
\hline
\end{tabular}


Pekerjaan kepala keluarga sebagian besar adalah petani/nelayan/buruh, yaitu 48,64 persen. Sedangkan pekerjaan ibu sebagian besar adalah tidak bekerja (52,08\%). Selanjutnya menurut tinggi badan ibu balita diketahui bahwa persentase ibu dengan tinggi badan kurang dari $150 \mathrm{~cm}$ sebesar 39,31 persen (Tabel 2).

Dari kelompok status ekonomi diketahui bahwa rumah tangga yang berada pada kuintil 1 dan kuintil 2 masing-masing sebesar 24,08 persen dan 23,10 persen. Sedangkan menurut pengeluaran rokok rumah tangga diketahui bahwa rumah tangga dengan pengeluaran rokok pada kuintil 3 sampai dengan kuintil 5 masing-masing sebesar 20 persen (Tabel 2). Menurut data Riskesdas 2007, sebanyak 69 persen rumah tangga memiliki pengeluaran untuk rokok, dengan kata lain minimal terdapat satu anggota rumah tangga yang merokok.

Rata-rata pengeluaran rokok rumah tangga sebulan, yaitu sebesar Rp.153.179 $\pm \mathrm{Rp}$. $200.815,-,$. Sedangkan persen rata-rata pengeluaran rokok dibandingkan dengan pengeluaran total rumah tangga sebulan sebesar $7,54 \% \pm 8,03 \%$.

Tabel 3

Distribusi Status Gizi (BB/TB) menurut Karakteristik Balita, Riskesdas 2010

\begin{tabular}{cccccc}
\hline \multirow{2}{*}{$\begin{array}{c}\text { Karakteristik Balita } \\
\text { Jenis kelamin }\end{array}$} & $\mathrm{n}=11500$ & \multicolumn{4}{c}{ Persen Status Gizi (BB/TB) } \\
\cline { 3 - 6 } & & Sangat kurus & Kurus & Normal & Gemuk \\
\hline$\quad$ Laki-laki & 5687 & 5,90 & 7,40 & 76,10 & 10,60 \\
$\circ \quad$ Perempuan & 5813 & 5,20 & 7,00 & 75,40 & 12,40 \\
\hline Kelompok umur & & & & & \\
$\circ \quad$ 0-11 bulan & 1534 & 6,74 & 8,03 & 66,72 & 18,51 \\
$\circ \quad$ 12-23 bulan & 2580 & 5,92 & 8,21 & 74,77 & 11,10 \\
$\circ \quad 24-35$ bulan & 2578 & 6,47 & 6,73 & 76,63 & 10,17 \\
$\circ \quad 36-47$ bulan & 2556 & 4,51 & 6,40 & 78,69 & 10,40 \\
$\circ \quad 48-59$ bulan & 2252 & 4,50 & 6,43 & 78,25 & 10,82 \\
\hline
\end{tabular}

Dari distribusi status gizi balita (BB/TB) menurut jenis kelamin diketahui bahwa persentase laki-laki dengan status gizi sangat kurus sebesar 5,9 persen sedikit lebih tinggi dibandingkan perempuan $(5,2 \%)$. Demikian juga dengan persentase status gizi kurus, di mana persentase laki-laki sedikit lebih tinggi dibandingkan perempuan, ada perbedaan sebesar 0,4 persen. Menurut kelompok umur diketahui bahwa persentase status gizi sangat kurus tertinggi terdapat pada kelompok umur 011 bulan yaitu sebesar 6,74 persen. Sedangkan persentase status gizi kurus tertinggi terdapat pada kelompok umur $12-23$ bulan $(8,21 \%)$ (Tabel 3).

Tabel 4 menunjukkan bahwa menurut jenis kelamin persentase status gizi sangat pendek maupun status gizi pendek cenderung lebih tinggi pada laki-laki dibandingkan perempuan. Sedangkan menurut kelompok umur diketahui bahwa persentase status gizi sangat pendek tertinggi terdapat pada kelompok umur 24-35 bulan $(24,95 \%)$. Kemudian persentase status gizi pendek tertinggi terdapat pada kelompok umur 48-59 bulan, yaitu 23,92 persen. 
Tabel 4

Distribusi Status Gizi (TB/U) menurut Karakteristik Balita, Riskesdas 2010

\begin{tabular}{ccccc}
\hline \multirow{2}{*}{ Karakteristik Balita } & $\mathrm{n}=11500$ & \multicolumn{3}{c}{ Persen Status Gizi (TB/U) } \\
\cline { 3 - 5 } & & Sangat pendek & Pendek & Normal \\
\hline $\begin{array}{c}\text { Jenis kelamin } \\
\quad \text { Laki-laki }\end{array}$ & 5687 & 22,40 & 22,00 & 55,60 \\
$\quad$ Perempuan & 5813 & 21,00 & 21,00 & 58,00 \\
\hline Kelompok umur & & & & \\
$\circ \quad$ 0-11 bulan & 1534 & 18,17 & 13,29 & 68,54 \\
$\circ \quad 12-23$ bulan & 2580 & 23,21 & 20,89 & 55,90 \\
$\circ \quad 24-35$ bulan & 2578 & 24,95 & 22,58 & 52,47 \\
$\circ \quad 36-47$ bulan & 2556 & 20,90 & 23,23 & 55,87 \\
$\circ \quad 48-59$ bulan & 2252 & 19,20 & 23,92 & 56,88 \\
\hline
\end{tabular}

Tabel 5 menunjukkan bahwa menurut jenis kelamin persentase status gizi buruk dan status gizi kurang cenderung lebih tinggi pada laki-laki dibandingkan perempuan. Sedangkan menurut kelompok umur, persentase status gizi buruk dan status gizi kurang tertinggi terdapat pada kelompok umur 48-59 bulan, yaitu sebesar 5,2 persen dan 19,1 persen.

Tabel 5

Distribusi Status Gizi (BB/U) menurut Karakteristik Balita, Riskesdas 2010

\begin{tabular}{|c|c|c|c|c|c|c|}
\hline \multirow{2}{*}{\multicolumn{2}{|c|}{ Karakteristik Balita }} & \multirow[b]{2}{*}{$n=11500$} & \multicolumn{4}{|c|}{ Persen Status Gizi (BB/U) } \\
\hline & & & $\begin{array}{l}\text { Gizi } \\
\text { Buruk }\end{array}$ & $\begin{array}{c}\text { Gizi } \\
\text { Kurang }\end{array}$ & $\begin{array}{l}\text { Gizi } \\
\text { Baik }\end{array}$ & $\begin{array}{l}\text { Gizi } \\
\text { Lebih }\end{array}$ \\
\hline \multicolumn{7}{|c|}{ Jenis kelamin } \\
\hline o & Laki-laki & 5687 & 5,10 & 17,60 & 75,00 & 2,30 \\
\hline & Perempuan & 5813 & 4,70 & 15,50 & 77,20 & 2,60 \\
\hline \multicolumn{7}{|c|}{ Kelompok umur } \\
\hline o & $0-11$ bulan & 1534 & 3,81 & 9,80 & 83,37 & 3,02 \\
\hline o & 12-23 bulan & 2580 & 4,75 & 13,44 & 79,17 & 2,64 \\
\hline 0 & 24-35 bulan & 2578 & 4,44 & 18,96 & 74,46 & 2,14 \\
\hline o & $36-47$ bulan & 2556 & 5,19 & 17,70 & 74,67 & 2,44 \\
\hline 0 & $48-59$ bulan & 2252 & 5,20 & 19,10 & 73,32 & 2,38 \\
\hline
\end{tabular}

\section{Status Gizi Balita (BB/TB) menurut Karakteristik Keluarga}

Menurut pendidikan kepala keluarga dan ibu balita memperlihatkan adanya kecenderungan penurunan persentase status gizi sangat kurus dengan semakin meningkatnya tingkat pendidikan kepala keluarga maupun ibu balita. Sedangkan menurut pekerjaan kepala keluarga diketahui bahwa persentase status gizi sangat kurus tertinggi terdapat pada kepala keluarga yang bekerja sebagai petani/nelayan/buruh, yaitu sebesar 6,05 persen. Demikian juga menurut pekerjaan ibu, persentase status gizi sangat kurus tertinggi terdapat pada ibu yang bekerja sebagai petani/nelayan/buruh $(5,98 \%)$. Dilihat dari tinggi badan ibu balita, persentase status gizi sangat kurus cenderung lebih tinggi pada ibu dengan tinggi badan kurang dari $150 \mathrm{~cm}$, yaitu sebesar 5,73 persen (Tabel 6). 
Tabel 6

Distribusi Status Gizi Balita (BB/TB) menurut Karakteristik Keluarga, Riskesdas 2010

\begin{tabular}{|c|c|c|c|c|c|}
\hline \multirow{2}{*}{ Karakteristik Keluarga } & \multirow{2}{*}{$n=11500$} & \multicolumn{4}{|c|}{ Persen Status Gizi (BB/TB) } \\
\hline & & Sangat kurus & Kurus & Normal & Gemuk \\
\hline \multicolumn{6}{|l|}{ Pendidikan KK } \\
\hline SMP & 2207 & 6,16 & 6,80 & 75,31 & 11,73 \\
\hline SMA & 3132 & 4,54 & 6,54 & 76,41 & 12,51 \\
\hline PT & 923 & 4,38 & 6,77 & 73,65 & 15,20 \\
\hline \multicolumn{6}{|l|}{ Pekerjaan KK } \\
\hline TNI/PNS/Sekolah & 1290 & 3,87 & 4,47 & 76,89 & 14,77 \\
\hline Wiraswasta/pedagang & 3977 & 5,46 & 6,79 & 75,02 & 12,73 \\
\hline Tidak kerja/lainnya & 639 & 5,38 & 6,16 & 78,21 & 10,25 \\
\hline Petani/nelayan/buruh & 5594 & 6,05 & 8,05 & 75,60 & 10,30 \\
\hline \multicolumn{6}{|l|}{ Tinggi badan ibu } \\
\hline$<150 \mathrm{~cm}$ & 4521 & 5,73 & 6,69 & 77,78 & 9,80 \\
\hline$>=150 \mathrm{~cm}$ & 6979 & 5,44 & 7,36 & 74,35 & 12,85 \\
\hline \multicolumn{6}{|l|}{ Pendidikan ibu } \\
\hline$<=S D$ & 4920 & 6,34 & 7,90 & 75,42 & 10,34 \\
\hline SMP & 2633 & 5,66 & 6,77 & 75,30 & 12,27 \\
\hline SMA & 3032 & 4,93 & 6,57 & 76,40 & 12,10 \\
\hline PT & 915 & 3,19 & 5,56 & 75,86 & 15,39 \\
\hline \multicolumn{6}{|l|}{ Pekerjaan ibu } \\
\hline Tidak bekerja & 5989 & 5,57 & 7,22 & 76,47 & 10,74 \\
\hline PNS/TNI/Wiraswasta & 2137 & 4,85 & 6,51 & 74,60 & 14,04 \\
\hline Petani/buruh/nelayan & 3374 & 5,98 & 7,27 & 74,99 & 11,76 \\
\hline \multicolumn{6}{|l|}{ Sosial ekonomi } \\
\hline Kuintil 1 & 2770 & 6,21 & 8,83 & 73,87 & 11,09 \\
\hline Kuintil 2 & 2656 & 6,30 & 7,06 & 75,76 & 10,88 \\
\hline Kuintil 3 & 2451 & 5,76 & 6,74 & 76,24 & 11,26 \\
\hline Kuintil 4 & 2150 & 4,81 & 6,21 & 76,89 & 12,09 \\
\hline Kuintil 5 & 1473 & 3,69 & 5,74 & 76,36 & 14,21 \\
\hline \multicolumn{6}{|l|}{ Pengeluaran rokok RT } \\
\hline Kuintil 1 & 3194 & 5,15 & 6,84 & 75,41 & 12,60 \\
\hline Kuintil 2 & 1406 & 4,42 & 5,90 & 78,47 & 11,21 \\
\hline Kuintil 3 & 2300 & 4,60 & 7,22 & 76,86 & 11,32 \\
\hline Kuintil 4 & 2300 & 6,28 & 7,47 & 74,98 & 11,27 \\
\hline Kuintil 5 & 2300 & 7,09 & 7,70 & 73,87 & 11,34 \\
\hline
\end{tabular}

Selanjutnya menurut status ekonomi rumah tangga menunjukkan adanya kecenderungan penurunan persentase status gizi sangat kurus dengan meningkatnya kuintil. Sebagaimana diketahui persentase status gizi sangat kurus tinggi terdapat pada kuintil 1 dan kuintil 2, dan persentase status gizi sangat kurus terendah terdapat pada kuintil $5(3,69 \%)$.

Kemudian menurut pengeluaran rokok rumah tangga menunjukkan adanya kecenderungan peningkatan persentase status gizi sangat kurus dari kuintil 2 sampai dengan kuintil 5. Persentase status gizi sangat kurus terendah terdapat pada kuintil $2(4,42 \%)$ dan persentase status gizi sangat kurus tertinggi terdapat pada kuintil 5 (7,09\%).

\section{Status Gizi Balita (TB/U) menurut Karakteristik Keluarga}

Tabel 7 menunjukkan distribusi status gizi balita (TB/U) menurut karakteristik keluarga. 
Menurut pendidikan kepala keluarga dan ibu balita menunjukkan adanya kecenderungan penurunan persentase status gizi sangat pendek dengan semakin meningkatnya tingkat pendidikan kepala keluarga maupun ibu balita. Sedangkan menurut pekerjaan kepala keluarga diketahui bahwa persentase status gizi sangat pendek tertinggi terdapat pada kepala keluarga yang bekerja sebagai petani/nelayan/buruh, yaitu sebesar 24,22 persen.
Demikian juga menurut pekerjaan ibu, persentase status gizi balita sangat pendek tertinggi terdapat pada ibu yang bekerja sebagai petani/nelayan/buruh, yaitu sebesar 25,82 persen. Selanjutnya dilihat dari tinggi badan ibu balita, persentase status gizi balita sangat pendek cenderung lebih tinggi pada ibu dengan tinggi badan kurang dari $150 \mathrm{~cm}$, yaitu sebesar 26,14 persen.

Tabel 7

Distribusi Status Gizi (TB/U) menurut Karakteristik Keluarga, Riskesdas 2010

\begin{tabular}{|c|c|c|c|c|}
\hline \multirow{2}{*}{ Karakteristik Keluarga } & \multirow{2}{*}{$n=11500$} & \multicolumn{3}{|c|}{ Persen Status Gizi (TB/U) } \\
\hline & & Sangat pendek & Pendek & Normal \\
\hline \multicolumn{5}{|l|}{ Pendidikan KK } \\
\hline SMP & 2207 & 22,03 & 22,42 & 55,55 \\
\hline SMA & 3132 & 19,24 & 19,16 & 61,60 \\
\hline PT & 923 & 11,66 & 16,42 & 71,92 \\
\hline \multicolumn{5}{|l|}{ Pekerjaan KK } \\
\hline TNI/PNS/Sekolah & 1290 & 16,36 & 18,08 & 65,56 \\
\hline Wiraswasta/pedagang & 3977 & 19,86 & 20,34 & 59,80 \\
\hline Tidak kerja/lainnya & 639 & 21,06 & 21,21 & 57,73 \\
\hline Petani/nelayan/buruh & 5594 & 24,22 & 22,96 & 52,82 \\
\hline \multicolumn{5}{|l|}{ Tinggi badan ibu } \\
\hline$<150 \mathrm{~cm}$ & 4521 & 26,14 & 24,61 & 49,25 \\
\hline$>=150 \mathrm{~cm}$ & 6979 & 18,73 & 19,23 & 62,04 \\
\hline \multicolumn{5}{|l|}{ Pendidikan ibu } \\
\hline$<=\mathrm{SD}$ & 4920 & 25,12 & 23,04 & 51,84 \\
\hline SMP & 2633 & 21,52 & 22,56 & 55,92 \\
\hline SMA & 3032 & 18,31 & 19,32 & 62,37 \\
\hline PT & 915 & 14,48 & 16,19 & 69,33 \\
\hline \multicolumn{5}{|l|}{ Pekerjaan ibu } \\
\hline Tidak bekerja & 5989 & 20,50 & 21,74 & 57,76 \\
\hline PNS/TNI/Wiraswasta & 2137 & 18,21 & 19,75 & 62,04 \\
\hline Petani/buruh/nelayan & 3374 & 25,82 & 21,81 & 52,37 \\
\hline \multicolumn{5}{|l|}{ Sosial ekonomi } \\
\hline Kuintil 1 & 2770 & 27,52 & 23,27 & 49,21 \\
\hline Kuintil 2 & 2656 & 24,40 & 22,85 & 52,75 \\
\hline Kuintil 3 & 2451 & 19,20 & 22,25 & 58,55 \\
\hline Kuintil 4 & 2150 & 17,77 & 19,64 & 62,59 \\
\hline Kuintil 5 & 1473 & 14,90 & 16,24 & 68,86 \\
\hline \multicolumn{5}{|l|}{ Pengeluaran rokok RT } \\
\hline Kuintil 1 & 3194 & 21,31 & 20,17 & 58,52 \\
\hline Kuintil 2 & 1406 & 20,21 & 20,59 & 59,20 \\
\hline Kuintil 3 & 2300 & 19,24 & 22,91 & 57,85 \\
\hline Kuintil 4 & 2300 & 22,73 & 21,32 & 55,95 \\
\hline Kuintil 5 & 2300 & 24,25 & 22,13 & 53,62 \\
\hline
\end{tabular}


Selanjutnya menurut status ekonomi rumah tangga menunjukkan adanya kecenderungan penurunan persentase status gizi sangat pendek dengan meningkatnya kuintil. Sebagaimana diketahui persentase status gizi sangat pendek tertinggi terdapat pada kuintil 1 $(27,52 \%)$, dan persentase status gizi sangat pendek terendah terdapat pada kuintil 5 $(14,9 \%)$.

Kemudian menurut pengeluaran rokok rumah tangga menunjukkan adanya kecenderungan peningkatan persentase status gizi sangat pendek dari kuintil 3 sampai dengan kuintil 5. Persentase status gizi sangat pendek terendah terdapat pada kuintil $3(19,24 \%)$ dan persentase status gizi sangat pendek tertinggi terdapat pada kuintil $5(24,25 \%)$.

\section{Status Gizi Balita (BB/U) menurut Karakteristik Keluarga}

Distribusi status gizi balita (BB/U) menurut karakteristik keluarga disajikan pada Tabel 8 di bawah ini.

Tabel 8

Distribusi Status Gizi (BB/U) menurut Karakteristik Keluarga, Riskesdas 2010

\begin{tabular}{|c|c|c|c|c|c|}
\hline \multirow[b]{2}{*}{ Karakteristik Keluarga } & \multirow[b]{2}{*}{$n=11500$} & \multicolumn{4}{|c|}{ Persen Status Gizi (BB/U) } \\
\hline & & $\begin{array}{c}\text { Gizi } \\
\text { Buruk }\end{array}$ & $\begin{array}{c}\text { Gizi } \\
\text { Kurang }\end{array}$ & $\begin{array}{l}\text { Gizi } \\
\text { Baik } \\
\end{array}$ & $\begin{array}{c}\text { Gizi } \\
\text { Lebih }\end{array}$ \\
\hline \multicolumn{6}{|l|}{ Pendidikan KK } \\
\hline SMP & 2207 & 4,21 & 16,66 & 76,94 & 2,19 \\
\hline SMA & 3132 & 3,51 & 14,40 & 79,22 & 2,87 \\
\hline PT & 923 & 3,50 & 8,51 & 83,22 & 4,77 \\
\hline \multicolumn{6}{|l|}{ Pekerjaan KK } \\
\hline TNI/PNS/Sekolah & 1290 & 2,53 & 11,85 & 82,75 & 2,87 \\
\hline Wiraswasta/pedagang & 3977 & 4,02 & 14,67 & 78,36 & 2,95 \\
\hline Tidak kerja/lainnya & 639 & 5,33 & 14,44 & 77,03 & 3,20 \\
\hline Petani/nelayan/buruh & 5594 & 5,73 & 18,69 & 73,62 & 1,96 \\
\hline \multicolumn{6}{|l|}{ Tinggi badan ibu } \\
\hline$<150 \mathrm{~cm}$ & 4521 & 6,36 & 20,27 & 71,65 & 1,72 \\
\hline$>=150 \mathrm{~cm}$ & 6979 & 3,71 & 13,70 & 79,62 & 2,97 \\
\hline \multicolumn{6}{|l|}{ Pendidikan ibu } \\
\hline$<=S D$ & 4920 & 6,14 & 18,64 & 73,45 & 1,77 \\
\hline SMP & 2633 & 3,79 & 17,40 & 76,85 & 1,96 \\
\hline SMA & 3032 & 4,02 & 13,68 & 79,09 & 3,21 \\
\hline PT & 915 & 2,56 & 9,02 & 83,06 & 5,36 \\
\hline \multicolumn{6}{|l|}{ Pekerjaan ibu } \\
\hline Tidak bekerja & 5989 & 4,59 & 16,54 & 76,78 & 2,09 \\
\hline PNS/TNI/Wiraswasta & 2137 & 3,49 & 13,39 & 79,67 & 3,45 \\
\hline Petani/buruh/nelayan & 3374 & 5,81 & 17,62 & 74,01 & 2,56 \\
\hline \multicolumn{6}{|l|}{ Sosial ekonomi } \\
\hline Kuintil 1 & 2770 & 6,96 & 20,28 & 70,72 & 2,04 \\
\hline Kuintil 2 & 2656 & 4,83 & 17,48 & 75,44 & 2,25 \\
\hline Kuintil 3 & 2451 & 4,03 & 16,22 & 77,68 & 2,07 \\
\hline Kuintil 4 & 2150 & 3,85 & 13,56 & 80,15 & 2,44 \\
\hline Kuintil 5 & 1473 & 2,83 & 10,36 & 82,32 & 4,49 \\
\hline \multicolumn{6}{|l|}{ Pengeluaran rokok RT } \\
\hline Kuintil 1 & 3194 & 4,23 & 15,09 & 78,24 & 2,44 \\
\hline Kuintil 2 & 1406 & 4,10 & 14,44 & 79,00 & 2,46 \\
\hline Kuintil 3 & 2300 & 4,72 & 16,66 & 75,71 & 2,91 \\
\hline Kuintil 4 & 2300 & 4,79 & 17,35 & 75,36 & 2,50 \\
\hline Kuintil 5 & 2300 & 5,85 & 17,57 & 74,47 & 2,11 \\
\hline
\end{tabular}


Menurut pendidikan kepala keluarga dan ibu balita menunjukkan adanya kecenderungan penurunan persentase status gizi buruk dengan semakin meningkatnya tingkat pendidikan kepala keluarga maupun ibu balita. Sedangkan menurut pekerjaan kepala keluarga diketahui bahwa persentase status gizi buruk tertinggi terdapat pada kepala keluarga yang bekerja sebagai petani/nelayan/buruh, yaitu sebesar 5,73 persen. Demikian juga menurut pekerjaan ibu, persentase status gizi buruk tertinggi terdapat pada ibu yang bekerja sebagai petani/nelayan/buruh $(5,81 \%)$. Dilihat dari tinggi badan ibu balita, persentase status gizi buruk cenderung lebih tinggi pada ibu dengan tinggi badan di bawah $150 \mathrm{~cm}$, yaitu sebesar 6,36 persen.

Selanjutnya menurut status ekonomi rumah tangga menunjukkan adanya kecenderungan penurunan persentase status gizi buruk dengan meningkatnya kuintil. Sebagaimana diketahui persentase status gizi buruk tertinggi terdapat pada kuintil $1(6,96 \%)$, dan persentase status gizi sangat kurus terendah terdapat pada kuintil $5(2,83 \%)$.

Kemudian menurut pengeluaran rokok rumah tangga menunjukkan adanya kecenderungan peningkatan persentase status gizi buruk dari kuintil 2 sampai dengan kuintil 5 . Persentase status gizi buruk terendah terdapat pada kuintil $2(4,1 \%)$ dan persentase status gizi buruk tertinggi terdapat pada kuintil $5(5,85 \%)$.

\section{Hubungan Pengeluaran Rokok Rumah tangga dengan Status Gizi Balita}

Dari pemodelan hubungan pengeluaran rokok rumah tangga dengan status gizi balita (BB/TB) menunjukkan bahwa rumah tangga dengan pengeluaran rokok pada kuintil 4 dan 5 memiliki odds rasio 1,21 kali $(\mathrm{Cl} 95 \%$ : 1,08 1,36 ) untuk berisiko mempunyai balita dengan status gizi (BB/TB) kurus dan sangat kurus dibandingkan rumah tangga dengan pengeluaran rokok pada kuintil 1,2 , dan 3 setelah dikontrol oleh variabel pendidikan ibu, pendidikan KK, dan pekerjaan KK (Tabel 9).

Tabel 9

Pemodelan Akhir Hubungan Pengeluaran Rokok Rumah tangga dengan Status Gizi Balita (BB/TB), Riskesdas 2010

\begin{tabular}{llccc}
\hline \multirow{2}{*}{ Variabel } & & Odds Rasio & Cl 95\% & p \\
& & & & \\
\hline Pengeluaran rokok & Kuintil 1-3 & & \\
& Kuintil 4-5 & 1,21 & $1,08-1,36$ & 0,001 \\
\hline Pendidikan ibu & PT & & & \\
& SMA & 1,37 & $1,03-1,81$ & 0,027 \\
& SMP & 1,42 & $1,05-1,93$ & 0,021 \\
& $<=$ SD & 1,61 & $1,19-2,17$ & 0,002 \\
\hline Pendidikan KK & PT & & & \\
& SMA & 0,68 & $0,52-0,89$ & 0,006 \\
& SMP & 0,70 & $0,51-0,95$ & 0,024 \\
& $<=$ SD & 0,68 & $0,50-0,92$ & 0,014 \\
\hline Pekerjaan KK & TNI/PNS/Sekolah & & & \\
& Wiraswasta/pedagang & 1,52 & $1,19-1,94$ & 0,001 \\
& Tidak kerja/lainnya & 1,43 & $1,02-2,00$ & 0,037 \\
& Petani/nelayan/buruh & 1,70 & $1,31-2,21$ & 0,000 \\
\hline
\end{tabular}

Kemudian dari pemodelan hubungan pengeluaran rokok rumah tangga dengan status gizi balita (TB/U) menunjukkan bahwa rumah tangga dengan pengeluaran rokok pada kuintil 4 dan 5 memiliki odds rasio 1,04 kali (Cl 95\%: $0,96-1,13)$ untuk berisiko mempunyai balita dengan status gizi (TB/U) pendek dan sangat pendek dibandingkan rumah tangga dengan pengeluaran rokok pada kuintil 1,2 , dan 3 setelah dikontrol oleh variabel tinggi badan ibu, pendidikan kepala keluarga, pekerjaan ibu, dan status ekonomi (Tabel 10). 
Tabel 10

Pemodelan Akhir Hubungan Pengeluaran Rokok Rumah tangga dengan Status Gizi Balita (TB/U), Riskesdas 2010

\begin{tabular}{llccc}
\hline Variabel & & Odds Rasio & Cl 95\% & $p$ \\
\hline Pengeluaran rokok & Kuintil 1-3 & & & \\
& Kuintil 4-5 & 1,04 & $0,96-1,13$ & 0,247 \\
\hline Tinggi badan ibu & $>=150 \mathrm{~cm}$ & & & \\
& $<150 \mathrm{~cm}$ & 1,58 & $1,46-1,71$ & 0,000 \\
\hline Pendidikan KK & PT & & & \\
& SMA & 1,36 & $1,14-1,61$ & 0,000 \\
& SMP & 1,54 & $1,28-1,85$ & 0,000 \\
& $<=$ SD & 1,61 & $1,35-1,92$ & 0,000 \\
\hline Pekerjaan ibu & Tidak bekerja & & & \\
& PNS/TNI/Wiraswasta & 1,00 & $0,90-1,12$ & 0,918 \\
& Petani/buruh/nelayan & 1,10 & $1,02-1,22$ & 0,016 \\
\hline Status ekonomi & Kuintil 5 & & & \\
& Kuintil 4 & 1,19 & $1,02-1,38$ & 0,020 \\
& Kuintil 3 & 1,30 & $1,12-1,51$ & 0,000 \\
& Kuintil 2 & 1,58 & $1,36-1,84$ & 0,000 \\
& Kuintil 1 & 1,75 & $1,50-2,03$ & 0,000 \\
\hline
\end{tabular}

Selanjutnya dari hasil analisis multivariat hubungan pengeluaran rokok rumah tangga dengan status gizi balita $(B B / U)$ menunjukkan bahwa rumah tangga dengan pengeluaran rokok pada kuintil 4 dan 5 memiliki odds rasio 1,08 kali (Cl 95\%: 0,98 - 1,19) untuk berisiko mempunyai balita dengan status gizi (BB/U) kurang dan buruk dibandingkan rumah tangga dengan pengeluaran rokok pada kuintil 1,2 , dan 3 setelah dikontrol oleh variabel tinggi badan $\mathrm{ibu}$, pendidikan ibu, pendidikan KK, dan status ekonomi (Tabel 11).

Tabel 11

Pemodelan Akhir Hubungan Pengeluaran Rokok Rumah tangga dengan Status Gizi Balita (BB/U), Riskesdas 2010

\begin{tabular}{llccc}
\hline & Variabel & Odds Rasio & Cl 95\% & $p$ \\
\hline Pengeluaran rokok & Kuintil 1-3 & & & \\
& Kuintil 4-5 & 1,08 & $0,98-1,19$ & 0,103 \\
\hline Tinggi badan ibu & $>=150 \mathrm{~cm}$ & & & \\
& $<150 \mathrm{~cm}$ & 1,61 & $1,47-1,77$ & 0,000 \\
\hline Pendidikan ibu & PT & & & \\
& SMA & 1,30 & $1,02-1,66$ & 0,032 \\
& SMP & 1,42 & $1,09-1,84$ & 0,008 \\
& $<=$ SD & 1,53 & $1,18-1,99$ & 0,001 \\
\hline Pendidikan KK & PT & & & \\
& SMA & 1,18 & $0,93-1,51$ & 0,158 \\
& SMP & 1,20 & $0,92-1,56$ & 0,175 \\
& $<=$ SD & 1,30 & $1,00-1,68$ & 0,044 \\
\hline Status ekonomi & Kuintil 5 & & & \\
& Kuintil 4 & 1,22 & $1,01-1,49$ & 0,039 \\
& Kuintil 3 & 1,34 & $1,10-1,64$ & 0,003 \\
& Kuintil 2 & 1,45 & $1,19-1,76$ & 0,000 \\
& Kuintil 1 & 1,81 & $1,49-2,21$ & 0,000 \\
\hline
\end{tabular}




\section{BAHASAN}

Hasil penelitian menunjukkan bahwa ratarata pengeluaran rokok rumah tangga sebulan Rp.153.179 \pm Rp. 200.815,- sedikit di bawah dari temuan IAKMI (2010), yaitu sebesar Rp.216.000,- per bulan. Sedangkan persen rata-rata pengeluaran rokok dibanding pengeluaran total rumah tangga sebulan sebesar 7,54\% $\pm 8,03 \% .{ }^{11}$

Selanjutnya dari ketiga analisis pemodelan hubungan antara pengeluaran rokok rumah tangga dengan status gizi balita menunjukkan adanya kecenderungan penurunan status gizi balita dengan meningkatnya pengeluaran rokok rumah tangga. Rumah tangga dengan pengeluaran rokok pada kuintil 4 dan 5 memiliki odds rasio 1,21 kali (Cl 95\%: 1,08 - 1,36) untuk berisiko mempunyai balita dengan status gizi (BB/TB) kurus dan sangat kurus dibandingkan rumah tangga dengan pengeluaran rokok pada kuintil 1, 2, dan 3 setelah dikontrol oleh variabel pendidikan ibu, pendidikan $\mathrm{KK}$, dan pekerjaan KK.

Sebagaimana diketahui bahwa merokok tidak hanya merusak kesehatan, tetapi juga merusak ekonomi rumah tangga yang secara tidak langsung dapat mempengaruhi ketersediaan makanan dalam rumah tangga. Pengeluaran rokok oleh individu dalam rumah tangga menyebabkan peluang rumah tangga untuk menanggung biaya akibat penyakit yang ditimbulkan asap rokok meningkat, sekaligus menghilangkan peluang pendapatan rumah tangga.

Akibat penyakit yang ditimbulkan karena merokok maka ada beban biaya untuk pengobatan maupun biaya yang hilang akibat tidak dapat bekerja atau beraktivitas. Penelitian Ross et al. di China tahun 2000 menunjukkan bahwa biaya akibat rokok mencapai 0,06 persen dari Produk Domestik Bruto (PDB), sedangkan studi McGhee (1998) di Hong Kong mendapatkan bahwa biaya yang dikeluarkan akibat perokok aktif tahun 1998 mencapai US\$ 532 juta dan perokok pasif US\$ 156 juta. ${ }^{13,14}$ Kemudian studi Yang et al. (2005) di Taiwan mendapatkan bahwa biaya akibat rokok menghabiskan 68 persen total belanja medis penduduk usia 35 tahun ke atas..$^{15}$ Selanjutnya hasil kajian IAKMI dengan menggabungkan data Riskesdas 2007 dan Susenas 2007 menunjukkan bahwa merokok meningkatkan risiko terkena penyakit tuberkulosa dan asma, baik pada perokok maupun keluarga perokok, termasuk anak balita yang tinggal di rumah tangga perokok. Anak balita yang terkena TBC ataupun penyakit lain akibat rokok secara tidak langsung akan berpengaruh terhadap status gizi. ${ }^{11}$

Kerugian ekonomis akibat merokok lainnya adalah berkurangnya pendapatan rumah tangga yang diakibatkan pengeluaran untuk membeli rokok oleh individu dalam rumah tangga. Hasil kajian IAKMI (2010) menunjukkan bahwa pengeluaran rumah tangga miskin untuk rokok menempati urutan kedua setelah padi-padian dan 5 kali lebih banyak daripada pengeluaran untuk susu dan telur. Dengan kata lain perokok miskin lebih mementingkan membeli rokok daripada membeli susu dan telur. Kondisi ini menjadi lebih bermanfaat jika pendapatan rumah tangga digunakan untuk membeli makanan bergizi yang secara tidak langsung akan berkontribusi terhadap perbaikan gizi anggota rumah tangga, termasuk anak balita. ${ }^{11}$

Dengan demikian dapat dikatakan bahwa merokok menimbulkan beban kesehatan, sosial, ekonomi dan lingkungan. Pengendalian tembakau tidak merugikan perekonomian negara, namun justru memberikan dampak positif (IAKMI, 2010). ${ }^{11}$ Perlunya upaya pemerintah pusat maupun pemerintah daerah dalam pelarangan iklan rokok untuk melindungi masyarakat, terutama anak-anak dan remaja dari pencitraan produk tembakau yang menyesatkan. Pelarangan iklan rokok meliputi pelarangan: a) iklan, baik langsung maupun tidak langsung di semua media massa, b) promosi dalam berbagai bentuk, misalnya hadiah, potongan harga, c) sponsorship dalam bentuk pemberian beasiswa, pemberian bantuan untuk bidang pendidikan, kebudayaan, dan olahraga, dan lain-lain. Di samping itu perlu digalakkan program berhenti merokok di kantorkantor, dan sekolah, selain penerapan program kawasan bebas rokok di tempat-tempat umum.

\section{SIMPULAN DAN SARAN}

\section{Simpulan}

1. Dari status gizi balita (BB/TB) diketahui bahwa persentase balita sangat kurus dan balita kurus masing-masing adalah 5,52 persen dan 7,19 persen. Kemudian dari status gizi balita (TB/U) didapatkan balita 
sangat pendek sebesar 21,69 persen dan balita pendek sebesar 21,50 persen. Selanjutnya dari status gizi balita (BB/U) diketahui bahwa balita dengan gizi buruk sebesar 4,88 persen dan balita dengan gizi kurang sebesar 16,54 persen.

2. Rata-rata pengeluaran rokok rumah tangga sebulan Rp.153.179 \pm Rp. 200.815,-. Persen rata-rata pengeluaran rokok dibanding pengeluaran total rumah tangga sebulan sebesar $7,54 \% \pm 8,03 \%$.

3. Rumah tangga dengan pengeluaran rokok pada kuintil 4 dan 5 memiliki odds rasio 1,21 kali (Cl 95\%: 1,08 - 1,36) untuk berisiko mempunyai balita dengan status gizi (BB/TB) kurus dan sangat kurus dibandingkan rumah tangga dengan pengeluaran rokok pada kuintil 1, 2, dan 3 setelah dikontrol oleh variabel pendidikan ibu, pendidikan KK, dan pekerjaan KK.

4. Rumah tangga dengan pengeluaran rokok pada kuintil 4 dan 5 memiliki odds rasio 1,04 kali (Cl 95\%: 0,96 - 1,13) untuk berisiko mempunyai balita dengan status gizi (TB/U) pendek dan sangat pendek dibandingkan rumah tangga dengan pengeluaran rokok pada kuintil 1, 2, dan 3 setelah dikontrol oleh variabel tinggi badan ibu, pendidikan kepala keluarga, pekerjaan ibu, dan status ekonomi.

5. Rumah tangga dengan pengeluaran rokok pada kuintil 4 dan 5 memiliki odds rasio 1,08 kali (Cl 95\%: 0,98 - 1,19) untuk berisiko mempunyai balita dengan status gizi $(B B / U)$ kurang dan buruk dibandingkan rumah tangga dengan pengeluaran rokok pada kuintil 1, 2, dan 3 setelah dikontrol oleh variabel tinggi badan ibu, pendidikan ibu, pendidikan KK, dan status ekonomi

\section{Saran}

1. Bagi pemerintah pusat maupun pemerintah daerah diharapkan adanya upaya penegakan aturan terhadap pelarangan iklan tentang rokok.

2. Bagi pemerintah pusat dan pemerintah daerah perlu digalakkan program berhenti merokok di kantor-kantor, dan sekolah, di samping program kawasan bebas rokok di tempat-tempat umum.

3. Bagi peneliti, perlu adanya penelitian lanjutan terkait pengeluaran rokok rumah tangga dengan status gizi balita dengan desain penelitian yang berbeda.

\section{RUJUKAN}

1. World Bank, Human Development Report, 2003.

2. Departemen Kesehatan, 2008, Laporan Hasil Riset Kesehatan Dasar Tahun 2007, Jakarta.

3. United Nations International Children's Emergency Fund (UNICEF). Strategy for improved nutrition of children and women in developing countries. UNICEF Policy Review 1990-1 (E/ICEF/1990/L.6). New York, NY: UNICEF, 1990.

4. Notoatmodjo, S. 2003. IImu Kesehatan Masyarakat, Prinsip-prinsip Dasar. Jakarta: Rineka Cipta.

5. Riyadi H., dkk., Studi tentang Status Gizi pada Rumah tangga Miskin dan Tidak Miskin. Gizi Indonesia. 2006. 29(1):33-46.

6. Sukandar D., dkk. Studi Ketahanan Pangan pada Rumah tangga Miskin dan Tidak Miskin. Gizi Indonesia. 2006. 29(1):22-32.

7. Martianto D. dan Ariani M, Analisis Perubahan Konsumsi dan Pola Konsumsi Pangan Masyarakat dalam Dekade Terakhir, Prosiding Widya Karya Nasional Pangan dan Gizi VIII, Jakarta, LIPI, 2004.

8. http://community.um.ac.id. Merokok bisa miskin dan kurang gizi. 27 Januari 2010.

9. Direktorat Kesehatan dan Gizi Masyarakat Bappenas, Pengembangan Database Pembangunan Bidang Kesehatan dan Gizi Masyarakat, 2009.

10. BPS, 2008. Pengeluaran untuk Konsumsi Penduduk Indonesia 2008 Berdasarkan Hasil Susenas Panel Maret 2008, Buku 1, Jakarta.

11. Tobacco Control Support Center, IAKMI. Dan KPS PDKT, 2010, Bunga Rampai: Fakta Tembakau, Permasalahannya di Indonesia Tahun 2010, Jakarta.

12. Kosen, et al. 2009. Study on Medical Expenditures and Burden of Major Tobacco Attributed Diseases in Indonesia. Final Report. Submitted to WHO Indonesia. Nationale Institute of Health Research and Development. Center of Health Systems 
and Policy Research and Development. Jakarta.

13. Ross, et al. 2007, The Cost of Smoking in Vietnam: the Case of Inpatient Care. Tobacco Control 2007;16;405-409.

14. McGhee, et al. 2006. Cost of TobaccoRelated Diseases, Including Passive
Smoking in Hong Kong. Tobacco Control 2006;15;125-130.

15. Yang, et al. 2005. Smoking Attributable Medical Expenditures, Years of Potential Life Lost and the Cost of Premature Death in Taiwan. Tobacco Control 2005;14;62-70. 